Reviews in Digital Humanities • Vol. 2, No. 9

\title{
Review: Singing Box 331
}

Kate Galloway ${ }^{1}$

${ }^{1}$ Rensselaer Polytechnic Institute

Published on: Sep 13, 2021

DOI: $10.21428 / 3 e 88 f 64 f .13 c 711 f 2$

License: Creative Commons Attribution 4.0 International License (CC-BY 4.0). 


\section{Project}

Singing Box 331: Re-sounding Eighteenth-Century Mohican Hymns from the Moravian Archives

\section{Project Directors}

Rachel Wheeler, IUPUI

Sarah Eyerly,, Florida State University

\section{Project URL}

https://oieahc.wm.edu/digital-projects/oi-reader/singing-box-331-rachel-wheeler-saraheyerlyl

\section{Project Reviewer}

Kate Galloway, Rensselaer Polytechnic Institute

\section{Project Overview}

\section{Rachel Wheeler and Sarah Eyerly}

Singing Box 331 is an enhanced digital version of a print article that appeared in the October 2019 issue of the William and Mary Quarterly. The digital version includes the same text, figures, and notes as the print version and can be read in the same order, but it also includes numerous recordings, videos, additional text, and images not included in print. From the beginning, we envisioned the website as an enhanced version of a print article, rather than as a stand alone digital humanities project. Our desire to re-sound historic musical texts led us to imagine and work toward a digital presentation of our work.

Singing Box 331 takes an interdisciplinary, community engaged, collaborative approach to the examination of one hymn from a small pamphlet of Mohican-language hymn texts dating to the 1740s and preserved in the Moravian Archives in Bethlehem, Pennsylvania. The first Moravian missionaries arrived in the Mohican village of Shekomeko in the Taconic Mountains in New York in 1740, and the first Mohicanlanguage hymns were written several years later in 1744. The Moravians had a rich tradition of musical worship, which they brought with them to the missions. The mission records are among the most extensive documentation of interactions with Native peoples in early America. 
Singing Box 331 examines the hymn, "Jesu paschgon kia," from multiple angles, as represented in the Site Map, which we envisioned as a non-linear, visual table of contents that would allow readers to navigate through the text and multimedia resources.

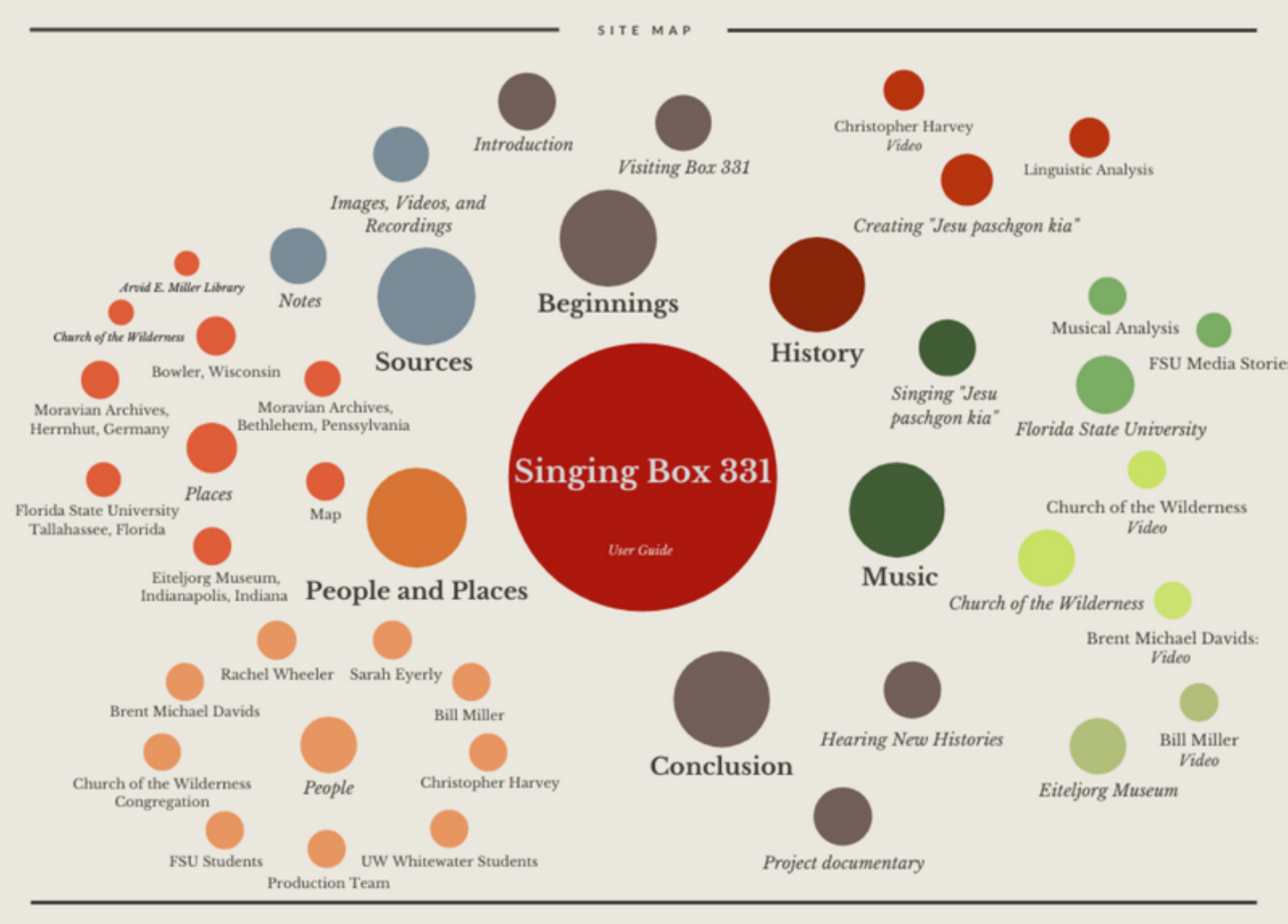

Sections of the article are devoted to the archival history of the hymns, the creation and use of the hymns in the 18th century, and finally, our efforts to re-sound these hymns in the 21st century in three different modes. The first recording relies on Moravian archival records to reconstruct the European Moravian musical traditions that informed the creation and performance of the hymns. The recording features students at Florida State University under the direction of Sarah Eyerly. The second recording features members of the Church of the Wilderness, a predominantly Mohican congregation on the Stockbridge Munsee Band Mohican Nation reservation in Bowler, Wisconsin, singing a modernized arrangement by Mohican composer Brent Michael Davids. The final recording is an entirely new musical rendering of the hymn by Grammy-winning Stockbridge Mohican singer-songwriter Bill Miller, recorded at IUPUI and premiered at a concert at the Eiteljorg Museum in Indianapolis in April 2018. 
Singing Box 331 is a work of interdisciplinary, collaborative, community-engaged scholarship that builds on Native American and Indigenous Studies (NAIS) methods seeking to decolonize early American archives through the co-creation of knowledge with members of a descendant community. The collaborative recordings of "Jesu pashgon kia" reveal the different meanings of the same historical text to multiple communities in the present, while also shedding new light on the 18th-century context in which the hymns were created.

The digital site seeks to reach a broader audience than is typically possible through the scholarly venue of the William and Mary Quarterly. The article speaks to scholars in the fields of NAIS, musicology, early American history, American religion, and ethnohistory, as well as tribal members, students, and the general public. The website is structured so readers can chart their own path through the material depending on their interests and their knowledge level: a member of the public might be interested in the documentary videos, but not delve into the scholarly text; a college student in a history course might be assigned to watch the documentary and read the historical section; a professor in musicology might assign the "Music" section, including the musical analysis and the recordings; a professor in NAIS might assign the introduction, conclusion, and additional sources to consider methodology. 

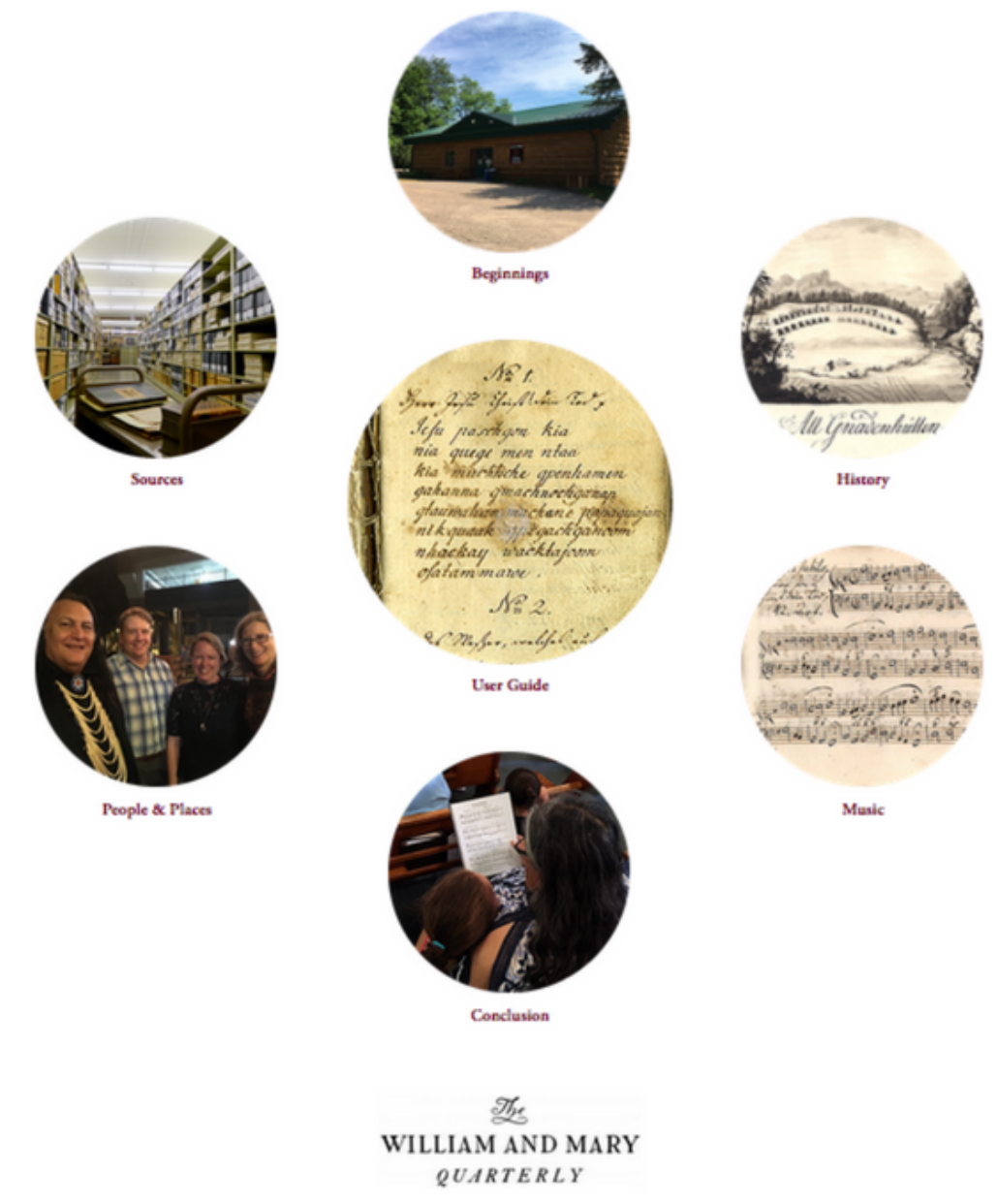

The primary collaborators are Rachel Wheeler, Associate Professor of Religious Studies at IUPUI, whose work includes a book on the history of Mohican encounters with missionaries, and Sarah Eyerly, Associate Professor of Musicology at Florida State University, whose work includes a book and digital project on the history of sound and music in Moravian communities. Other collaborators include composer and recording engineer Brent Michael Davids; musician Bill Miller; members of the Church of the Wilderness; linguist Chris Harvey; videographers Catherine Crouch, Lyz Sykes, Adam Stackhouse, Shuling Young, and Ladema Zinmeister; recording engineers John Hadden and Andy Nathan; the editorial team at the William and Mary Quarterly; and the web design team, Colour Outside.

The Singing Box 331 project was made possible with generous support from several institutions: the IUPUI Arts and Humanities Initiative, the IU School of Liberal Arts, the IU New Frontiers in the Humanities, the FSU College of Music, and the American Council of Learned Societies. The article won the Lester J. Cappon Award presented by 
the Omohundro Institute for the best article published in 2019 in the William and Mary Quarterly and the Robert F. Heizer Award for the best article in the field of ethnohistory published in 2019, presented by the American Society of Ethnohistory.

\section{Project Review}

\section{Kate Galloway}

Singing Box 331 is a digital history and musicology project that compiles, curates, and amplifies a range of documents that sound the past of 18th-century Mohican hymns located in the Moravian archives. Wheeler and Eyerly apply a precise focus, choosing to examine one hymn verse within one archival box to attend to broader questions concerning the history and aural environment of the Mohican hymns. The project features images of the archives, reproductions of archival documents, short project member videos highlighting their disciplinary contributions, a collection of contemporary recordings of "Jesu paschgon kia," and accessible text that untangles the social, musical, and linguistic histories of Singing Box 331.

The audible past of Singing Box 331 offers insight into the role of early Moravian mission work and the interpersonal, social, and sensory dynamics of the relationships between Native and European individuals and communities and listens to voices that have gone unheard or have remained silenced as a result of archival access. Singing Box 331 organizes these sonorous documents in a user-friendly, playful, and exploratory interactive digital environment. Users can either choose to follow the curated linear pathway to navigate the site by selecting the "next" tab to advance or they can use the non-linear, color-coded network map that affords users navigation agency and choice informed by their specific interests

Users hear the voices of Singing Box 331 through the contemporary recordings of the hymn verse "Jesu paschgon kia" and the project's detailed documentation of the recording process. Each recording takes a different approach to listening to and resounding the past and reminds users of the multiplicity of meanings that emerge from encounters with multisensory archival documents. The Stockbridge Mohican musicians Brent Michael Davids and Bill Miller have a different cultural investment in the hymn documents than the members of the congregation of the Lutheran Church of the Wilderness in Bowler, Wisconsin, and it is not surprising that each group voices the hymn using a different set of priorities. What sets Singing Box 331 apart from other digital history projects is that at every step in the research and remediation process, 
Wheeler and Eyerly attended to the sonic quality of their materials and continued listening and asking their collaborators to listen to these sonorous yet seemingly silent archival documents.

Listening to the past through Singing Box 331 is only possible because of Wheeler and Eyerly's interdisciplinary methodologies that draw from early American studies, including Moravian studies, sensory studies, hymnology, linguistics, and Indigenous studies. However, Singing Box 331 also provides a scholarly model for future work in digital history and sound studies in the ways the project draws on valuable knowledge systems beyond the academy by prioritizing relationships with Stockbridge Mohican community members to re-sound colonial archival silences. The inclusion of their communally held cultural knowledge is essential because their ties to the Mohicans of Shekomeko stretch back centuries, they are the only descendant community of the Mohicans, and because listening is a culturally and contextually situated process. 